Journal of Analytic Divinity

International Refereed Journal

E-ISSN: 2602-3792

Haziran/June, 2020/ 4 (1): ss-pp 167-182

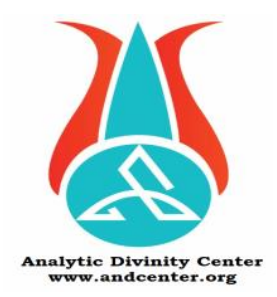

\title{
Irak Arapçasına Geçen ve Anlam Kaymasına Uğrayan Bazı Türkçe Kelimeler
}

Turkish Words Adopted by The Iraqi Arabic and Which Changed Meaning

Nur Özbek

Ankara Yıldırım Beyazıt Üniversitesi, Sosyal Bilimler Enstitüsü, Temel İslam Bilimleri

Bölümü, Department of Arabic Language and Rhetoric

Ankara-Turkey, nurozbek22@gmail.com

https:/ / orcid.org/6200-0810-0002-0000

\author{
Abdullah Hacıbekiroğlu \\ Dr. Öğr. Üyesi, Ankara Yıldırım Beyazıt Üniversitesi, Temel İslam Bilimleri, Arap Dili ve \\ Belagati Anabilim Dall. \\ Asst. Prof., Ankara Yıldırım Beyazıt University, Faculty of Islamic Sciences, Basic Islamic \\ Sciences, Department of Arabic Language and Rhetoric \\ Ankara-Turkey, ahacibekiroglu@ybu.edu.tr \\ https://orcid.org/ 0000-0002-1495-9728
}

\section{Makale Bilgisi | Article Information}

Makale Türü / Article Type: Araştırma Makalesi / Research Article

Geliş Tarihi / Date Received: Mart/ March 2020

Kabul Tarihi / Date Accepted: May1s/ May 2020

Yayın Tarihi / Date Published: 15 Haziran /15 June 2020

Yayın Sezonu / Pub Date Season: Yaz-Haziran / Summer-June

DOI: https://doi.org/10.46595/jad.721337

Cite as / Atıf: Özbek, Nur-Hacıbekiroğlu, Abdullah. "Irak Arapçasına Geçen ve Anlam Kaymasına Uğrayan Bazı Türkçe Kelimeler". Journal of Analytic Divinity, 4/1 (June 2020): 167-182.

İntihal: Bu makale, iThenticate yazılımınca taranmıştır. İntihal tespit edilmemiştir. Plagiarism: This article has been scanned by iThenticate. No plagiarism detected. web: http:/ / dergipark.gov.tr/jad | e-mail to: editorjand@gmail.com

Copyright ( Published by Özcan Güngör, Ankara Yıldırım Beyazıt Üniversitesi, İslami İlimler Fakültesi / Ankara Yıldırım Beyazıt University, Faculty of Islamic Studies, Ankara-Turkey. Bütün hakları saklıdır. / All right reserved. 
Öz

Tarih boyunca halklar arasında doğrudan veya dolaylı olarak yaşanan iletişimler ve farklı kültürlerin bir araya gelmesi, dil açısından da etkileşimlerin görülmesine yol açmıştır. Türkçe de asırlar boyunca hem birçok dili etkilemiş hem de onlardan etkilenmiştir. Türkçenin en fazla etkileşim içerisinde bulunduğu dillerden biri de Arapçadır. Türkler ve Araplar ortak İslami kültüre dayalı tarihsel ve sosyokültürel anlamda derin bağlara sahiptir. Türklerin de Müslümanlığı kabul etmeleriyle birlikte bu iki dil arasındaki etkileşim kaçınılmaz hale gelmiş, birçok alanda kelime alış-verişi olmuştur. Özellikle Türkçe, Arapçanın çok etkisinde kalmış ve Arap dilinden birçok kelimeyi kendi diline aktarmıştır. Bununla beraber Arapçanın Türkçeye etkisi kadar olmasa da Türkçe de Arapçayı etkilemiş ve bu dile birçok unsur kazandırmıştır. Türkçeden Irak Arapçasına geçen kelimelerin çoğu Türkçedeki anlamılla kullanılır, fakat kelimelerin bir kısmı zamanla anlam değişikliğine uğramıştır. Öte yandan Türkçeden Irak Arapçasına geçen kelimelerin bazıları Türkçe asıllı değildir. Bu kelimelerin bir kısmı başka dillerden Türkçeye girmiş, zamanla Türk dilinde yaygın bir kullanım sahası elde etmiş, daha sonra Türkçe vasıtasıyla Arapçaya geçmiştir. Dolayısıyla bu çalışmamızda ele aldığımız kelimelerin arasında bu tür kelimelere yer verilmiştir. Bu makalede; Irak Arapçasındaki anlam değişikliğine uğrayan Türkçe kelimeleri incelemeye çalıştık. Zamanla tedavülden kalkan kelimeler ise çalışmamızın kapsamı dışında bırakılmıştır.

Anahtar Kelimeler: Arapça, Anlam Kayması, Dil Etkileşimi, Irak Arapçası, Türkçe.

\begin{abstract}
Throughout the history, through direct or indirect interactions and through different cultures coming together, interactions between languages also have come into existence. For centuries, the Turkish language has been influenced by and has influenced many other languages. One of the most interactive languages with Turkish is Arabic. Through their common Islamic culture, Turkish and Arabic people have many deep historical and sociocultural connections. With the Turks' conversion to Islam the mutual influence between Arabic and Turkish became inevitable with many words getting exchanged. For the most part, the Turkish language has been deeply influenced by the Arabic language and many words have been adopted from it. Although the influence wasn't as much vice-versa, the Arabic language has also gained many new elements from the Turkish language. Many words adopted by the Iraqi Arabic language from the Turkish language are used with their original Turkish meaning, but some adopted words have changed their meaning over time. Although adopted from the Turkish language, not all adopted words have a Turkish origin. Having a foreign origin within Turkish itself, these words became widespread through the Turkish language and were then adopted by the Iraqi Arabic language from the Turkish language. Such words have been also included in this study. In this article, we have inspected words in the Iraqi Arabic which were adopted from the Turkish language and which have changed their original meaning. Words which have fallen into disuse over time have been left out of the scope of this study.
\end{abstract}

Keywords: Arabic, Changing Meaning, Interaction Between Languages, Iraqi Arabic, Turkish. 


\section{Giriş}

Bir toplumun, diğer toplumlarla doğrudan veya dolaylı olarak hiçbir münasebeti olmadan varlığını sürdürmesi çok zordur. Bir arada yaşayan toplumların birbirleriyle iletişim kurması toplumsal yaşamın bir gereksinimi olarak ortaya çıkmaktadır. Toplumların birbiriyle bu etkileşim sonucu kelimeler sınır tanımadan başka bir milletin diline girebilir. ${ }^{1}$ Dolayısıyla tarih boyunca dillerin birbirlerinden etkilenmesi kadar doğal bir şey yoktur. ${ }^{2}$ Diller doğrudan veya dolaylı bir şekilde etkileşim içerisine girer. Birbirine komşu olan toplumların dilleri doğrudan bir etkileşim içerisine girerken komşu olmayanlarda ise dolaylı bir ilişki görülür. Komşu devlet veya toplumların dillerinin hem dilsel söz varlığı hem de kültürel alışveriş bakımından sıklıkla ilişki içerisinde oldukları bilinen bir durumdur. ${ }^{3}$

Türkçe de komşu olduğu toplumların dillerinden etkilendiği gibi kendi söz ve kültür varlığına ait unsurları bu dillere vermiştir.

Bugün yaşayan dillerin en yaşlılarından biri olarak Türkçe, bu tarih derinliği yanında mekânca da geniş bir coğrafyaya sahiptir. Türkçenin konuşucuları, bu geniş tarihsel süreç içerisinde birçok devlet kurmuşlar, komşuluklarında yer alan kavimlerden birçok bilgi öğrenmişler ve komşularına da birçok bilgi öğretmişlerdir. Türklerin komşularına öğrettikleri ile komşularından öğrendikleri bilgilerin adları, Türkçe ile ona komşu olarak yaşayan başka diller arasında, oldukça zengin bir söz alışverişine yol açmıştır. ${ }^{4}$

Türkçe yakın ve komşu olduğu toplumların dilleriyle tarihsel olarak etkileşim içerisinde olmuştur. En fazla ilişki kurduğu dillerden birisinin de Arapça olduğu bilinmektedir. Hatta Türkçenin söz varlığına veya gündelik kullanımına bakıldığında bu husus açık bir şekilde görülebilmektedir.

Türkler ile Araplar arasındaki ilk ilişkiler Hz. Ömer döneminde başlamıştır. III. (IX.) yüzyılda Türkler'in İslamiyet'i kabul etmesiyle iki toplum arasındaki gittikçe aratarak devam eden ilişkiler ve daha sonraki yıllarda Arap ülkelerinin uzun yıllar boyunca Osmanlı'nın hâkimiyetine girmesi sonucu, iki dil arasındaki etkileşim kaçınılmaz hale gelmiştir. ${ }^{5}$ Türkler ve Arapların uzun bir geçmişe dayanan bu münasebetlerin sonucunda Türkçe, Arapçanın yoğun tesiri altında kalmış ve bu dilden çok sayıda kelime almıştır. Arapçanın Türkçeye etkisi kadar olmasa da Türkçe de Arapçayı etkilemiştir ve bu dile pek çok kelimesini vermiştir.

Osmanlılar, fetihlerden sonra hâkimiyet sürdükleri bölgelerde Türkçe'nin yaygınlaştırılması veya yerleştirilmesi gibi bir çaba içinde olmamıştır. Diğer fethedilen ülkelerde olduğu gibi Arap ülkelerinde de dil ve kültürel açıdan büyük bir özgürlük tanınmıştır. Osmanlı Devleti'nde, özellikle din dili oluşu nedeniyle Arapçaya çok önem

\footnotetext{
1 Musa Alp, “Kelimelerin Göçü: Türkçe Nisbet Eki “-Ci” nin” Şam Bölgesi (Suriye, Ürdün, Filistin ve Lübnan)” Arap Halk Ağzında Kullanımı Hakkında Bir Araştırma”, Çukurova Üniversitesi Illahiyat Fakültesi Dergisi 7/1 (2007), 179-180.

2 Hasan Akreş, el-Hudûru't-Turkî fíl-lehceti'l-'Irâkinyye (Bağdat: Daru'ş-şuûni's-sakafiyyeti'l-'âmme, 2018 ), 37.

3 Mehmet Özeren, "Türkiye Türkçesi Ağılarındaki Rusça sözcükler”, Turkish Studies- International Periodical For The Languages, Literature and History of Turkish or Turkic 9/3 (2014), 1093.

4 Günay Karaağaç, Türkçe Verintiler Sözlüğü (Ankara: TDK, 2008), VI.

5 Zülfikar Tüccar, "Dahîl”, Türkiye Diyanet Vakfi İslam Ansiklopedisi (İstanbul: TDV Yay., 1993), 8/412.
} 


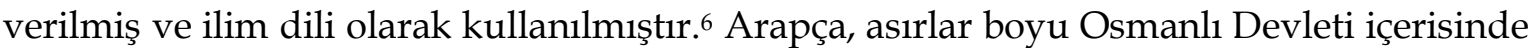
varlığını koruyabilmiştir. "Din ve hukuk bilimleri Kahire ve Şam'daki gibi, İstanbul'daki büyük okullarda da Arap diliyle öğretildi." 7 Osmanlı Devleti, farklı etniklere sahip birçok topluluğu içinde barındırmaktaydı. Bu farklı etnik gruplar arasındaki münasebetler; dini, ekonomi, siyasi, ticari, ilmi ve kültürel alanlarda çeşitli etkileşimlerin oluşmasına ve dolayısıyla dillerin de birbirinden etkilenmesine yol açmıştır. Arapça ve Türkçe de söz konusu bu etkileşimden payına düşeni almıştır. Öte yandan "yönetimdeki hâkim tabakanın dili olması sebebiyle Türkçe de Arapçayı etkilemiş, birçok Türkçe kelime Arapça'ya geçmiş ve bu kelimeler Arap Dili içinde yerlerini almıştır." 8 Arapçaya geçen Türkçe unsurların pek azı yazı diline geçebilmiştir. ${ }^{9}$ Ancak Türkçeden Arapçaya giren kelimeler daha çok konuşma dilinde kullanılmıştır. Irak Arapçasına geçen Türkçe kelimeler de genellikle konuşma dilinde kullanılmıştır. Bununla beraber bu kelimelerin bir kısmı zamanla anlam değişikliğine uğramıştır, kelimelerin bir kısmının Türkçedeki anlamlarından tamamen farklılaşarak kullanıldığını, diğer kısmının ise Türkçedeki anlamı ile birlikte yeni anlamlar kazanarak kullanılır hale geldiğini görmekteyiz. Bu çalışmada söz konusu türde olup Irak Arapçasında yaygın bir şekilde kullanılan kelimeler tespit edilip zamanla kullanımı giderek azalan ve tedavülden kalkmış olanlar ise kapsam dışında bırakılmıştır.

Türkçeden Irak Arapçasına çok sayıda kelime geçmesi ve günümüze kadar hâlâ kullanılıyor olmasında en büyük etken Osmanlı Devleti'nin on altıncı yüzyıldan yirminci yüzyıla kadar Irak'a hükmetmesi olmuştur. Bu anlamda Irak'ın tarihine ve Osmanlı dönemindeki yaşadığı sürece kısaca değinmek yerinde olacaktır.

\section{Irak Tarihine Genel Bir Bakış}

Resmî adı Cumhûriyyetu'l-'Irâk (جهورية العراق) olan ülke Arap yarımadasinın kuzeydoğusunda bulunmaktadır. Irak, "verimli hilal" olarak adlandırılan Mezopotamya bölgesinde yer almaktadır. Tarihte ilk çiftçilerin ortaya çıktığı bu bölge birçok medeniyete ev sahipliği yapmıştır. Bugün için bilinen en eski yazı, medeniyetler beşiği olarak bilinen ve Mezopotamya'nın güneyinde kurulan Sümer İmparatorluğu tarafından ilk kez kullanılmıştır. ${ }^{10}$ Irak'ta Dicle ve Fırat nehirlerinin varlığı tarihteki ilk uygarlıkların oluşmasında çok önemli bir rol oynamıştır.11 Fırat ile Dicle nehirleri sakinleri, çok eski çağlardan beri ticaret, seyahat veya fetihler yoluyla bölge dışından birçok farklı toplulukla bir araya gelmiştir. Dolayısıyla Mezopotamya medeniyeti onları etkilediği gibi onlardan

\footnotetext{
6 Bedrettin Aytaç, Arap Lehçelerindeki Türkçe Kelimeler (İstanbul: Türk Dünyası Araştırmaları Vakfı, 1994$), 17$.

7 Albert Hourani, Arap Halkları Tarihi, çev. Yavuz Alogan (İstanbul: İletişim, 1997), 287.

8 Aytaç, Arap Lehçelerindeki Türkçe Kelimeler, 18.

9 Şamil Fahri Yahya, Arapçanın Muhtelif Lehçelerinde Türkçe Unsurlar (İstanbul: İstanbul Üniversitesi, Doktora Tezi, 1984), XL.

10 Sait Yılmaz, Irak Dosyası (İstanbul: Kum Saati Yay., 2011), 17.

11 Selim Matar vd., “Lugatu'l-'Irâkî ve'l-'alemî”, Mevsuatu'l-lugati'l-'Irakiyye (Beyrut: Daru'l-kelimeti'l-hurre, 2009), 17.
} 
etkilenmiştir.12 Farklı kültürlerin bu karşılıklı ilişkisi, bölgenin gelişmiş bir medeniyete sahip olmasını sağlamıştır.

Etnik bir çeşitlilik arz eden Irak, ağırlıklı olarak Araplardan oluşmaktadır. Araplar Irak nüfusunun yaklaşık \%75-80'ini oluşturur. ${ }^{13}$ Arapların ardından Irak'taki en büyük etnik grubu ise Kürtler ve Türkmenler oluşturmaktadır. Araplar tarafından Cezîretu'l'Arab (جزيرة العرب) olarak adlandırılan Arap Yarımadası, Arapların temel yerleşim yerlerini teşkil etmekte olup bu bölgeden tarihin farklı dönemlerinde buraya pek çok göç meydana gelmiştir. ${ }^{14}$ İslamiyet'in ilk yıllarında Necid bölgesinden göç eden kabileler, ilk dönemlerde yeni kurulan Basra ve Kûfe gibi şehirlere yerleşmiştir ancak zaman içerisinde bu bölgenin tamamına yayılmıştır. ${ }^{15}$

Irak, "Emeviler ve Abbasiler döneminde en parlak dönemini yaşamıştır."16 Özellikle o dönemde Bağdat, İslam dünyasında ilmî faaliyetleriyle temayüz etmiş önemli merkezlerden biri haline gelmiştir. Hem fen bilimlerinde hem dil ve din ilimlerinde büyük gelişmelerin yaşandığı bir şehir olmuştur. Yöneticilerin ilmî çalışmalara destek vermesiyle İslam dünyasının diğer bölgelerinden âlimler buraya gelmiş ve ilim meclisleri yaygınlaşmıştır. İlim meclisleri ve yöneticilerin huzurlarında ilmî ve edebî münazaralar da yapılmıştır. ${ }^{17}$

Ne var ki Irak Devleti'nin farklı dini ve etnik grupları barındırıyor olması ve Arap, Kürt ve Türkmen çoğunluğundan oluşan bir nüfusa sahip olması, bu gruplar arasında sürekli iç gerilimin ve çatışmaların yaşanmasına neden olmuştur. Farklı ülkelerin çıkar elde etme amacıyla da bu çatışma ve gerilimleri desteklemesi, bu coğrafyada istikrarsızlığın devam etmesine yol açmıştır. Yirminci ve yirmi birinci yüzyılda Irak üzerindeki provokasyonlar artmış ülke gelişimi açısından gerilemeye neden olmuştur. Birçok savaşa sahne olan Bağdat, pek çok kez yıkıma uğramıştır. "Günümüzde Bağdat şehrinin eski görüntüsü değişmekle beraber, pek çok tarihi yapılar, hâlâ Bağdat'ı şarkın gizemli dünyasına götürmektedir."18

\section{Arapçanın Durumu ve Türkçenin Irak Arapçasının Üzerindeki Etkisi}

Arapça, Hami-Sami dil ailesinin Sami kolunun bir parçasıdır. İslam'ın iki temel kaynağı olan Kur'ân-1 Kerim ve Sünnetin dili olmasından ötürü Arapça Müslümanlar için büyük önem arz etmektedir. Fetihler aracılığıyla İslam Dininin yayılmasından sonra Arapça daha bir önem kazanmıştır. Müslümanların yönettiği bu fethedilen yerlerde siyaset, bilim ve edebiyat dili19 olarak kullanılmasının yanı sıra İslam'a yeni girenlerin de rağbet ettiği ve öğrenmek istediği bir dil haline gelmiştir.

\footnotetext{
12 Nezâr el-Hadîsî vd., Hadaretu'l-'Irak (Bağdat: Daru'l-huriyye, 1985), 1/ 19.

13 Haydar Karaalp, "Farklı etnik, dini ve mezhebi bileşenlerin mozaiği: Irak”, Anadolu Ajansı (26 Mart 2020).

14 Hussein Abbas Ali Muhammed Aslan, Kraliyet Devrinde Irak'ın Etnik Yapısı ve Siyasi Oluşumlar (Ankara: Gazi Üniversitesi, Sosyal Bilimler Enstitüsü, Yüksek Lisans Tezi, 2009), 25.

15 İmâdüddin Halîl, "Irak (Tarih)”, Türkiye Diyanet Vakfi İslam Ansiklopedisi, (İstanbul: TDV Yay., 1999), $19 / 88$.

16 Ramazan Özey, Dünya Denkleminde Ortadoğu Coğrafyası "Ülkeler-İnsanlar-Sorunlar", 3. Bs (İstanbul: Aktif, 2004), 223

17 İbrahim ed-Dakûkî, "Irak (Kültür ve Medeniyet)”, Türkiye Diyanet Vakfi İslam Ansiklopedisi, (İstanbul: TDV Yay., 1999), 19/103.

18 Özey, Dünya Denkleminde Ortadoğu Coğrafyası, 225.

19 Matar vd., "Lugatu'l-'Irâkî ve'l-'alemî", 133.
}

Journal of Analytic Divinity, https://dergipark.org.tr/tr/pub/jad Volume 4/1 
Arapçada, edebiyat ve yazı dili olan resmi Arapçaya Fasih dil (الفصحى), günlük hayatta halk arasında konuşulan Arapçaya lehçe (لهجة) veya diğer bir ifadeyle Âmmî dil (اللغة العامية) denir. ${ }^{20}$ Fushâ (لفصحى) kelimesi fesâhat (لفصاحة) mastarından türemiş olup açıklık ve netlik ${ }^{21}$ anlamına gelmektedir. Kur'ân dili fasih Arapça, cahiliye döneminden başlayarak günümüze kadar tarihin her döneminde varlığını korumuş ve geçmişte olduğu gibi günümüzde de kültür, edebiyat ve yazı dili22 olarak kullanılmaktadır. Üniversitelerde, konferanslarda, gazete, radyo ve iletişim araçlarında bu dil kullanılır. ${ }^{23}$ Yüzyıllardır geniş bir coğrafyada varlığını sürdüren Fasih Arapça, bu özelliği açısından benzersiz bir konuma sahiptir. Kelime hazinesi, anlam bakımından açıklığ 1 ve gramatik yapısıyla ayırt edici bir özelliğe sahip olan Fushâ'nın, Arapçada en yüksek dil seviyesi olduğu konusunda hiçbir kuşku yoktur.

Lehçe (هجة) denildiğinde, "belli bir çevreye ait bir takım dilsel özelliklerin olması ve bu özelliklerin o çevrede bulunan bireyler tarafından kullanılması" ${ }^{24}$ kastedilir.

Geniş kitleler tarafından kullanılan Arapça, konuşulduğu alanlara göre farklılıkları vardır ve yayıldığı coğrafyalarda birçok lehçesi bulunmaktadır. Lehçeler, temelini standart Arapçadan almış olup günlük yaşamda halk arasında konuşma dili olarak varlığını sürdürmektedir. ${ }^{25}$ "Lehçelerin farklılıklarında coğrafya, iklim ve fiziki etkenler etkili olabildiği gibi siyasi unsurlar, göç, savaş gibi toplumsal olaylar da etkili olabilmektedir" ${ }^{26}$

Kur'ân-1 Kerim inmeden önce Arap dilinde Temim, Kureyş, Rebi’a, Hozan ve Kays gibi farklı lehçeler mevcuttu. Bu lehçeler genel olarak; Temim lehçesi ve Hicaz lehçesi olmak üzere iki gruba ayrılır. Irak lehçesi, Temim lehçesinin birçok özelliğini taşımaktadır. Ancak, bu lehçe son yüzyıllarda Türkçe, Farsça ve İngilizcenin etkisinde kalmıştır. Bu nedenle, Türkçe, Farsça ve İngilizce kökenli birçok kelimeyi ihtiva etmiştir. ${ }^{27}$ “Türkçe, VII. yüzyılda Irak'ta kısmî bir konuşma dili olarak kullanılmaya başlanmış ve daha sonraki göçlerle yayılma ve kullanılma alanını genişletmiştir. XV. yüzyılda Karakoyunlular döneminde devlet dili olarak kabul edilmiş, Safevî ve Osmanlı dönemlerinde ise kültür ve edebiyat hayatının en vazgeçilmez dili olmuştur." 28

On üçüncü yüzyılda Osmanlı Devleti'nin gücü büyük bir gelişmeye sahne olmuştur. Nitekim Avrupa, Asya ve Afrika kıtalarında bulunan dünyanın birçok ülkesi Osmanlı'nın egemenliğine girmiş ve Osmanlı'nın nüfuzu arttıkça Türkçe de küresel bir dil haline

\footnotetext{
20 İmîl Bedî‘ Yakub-Mişel Asi, el-Mu'cemu'l-mufassal fi'l-luğa ve'l-edeb (Beyrut: Daru'l-ilm li'l-melayin, 1987), $1 / 1071$.

21 Yakub- Asi, el-Mu'cemu'l-mufassal fi'l-luğa, 1/924.

22 Yakub- Asi, el-Mu'cemu'l-mufassal fi'l-luğa, 1/1071.

23 Muhammed el-Tuncî, el-Mu'cemu'l-mufassal fi'l-edeb, 2. Bs (Beyrut: Daru'l-kütübi'l-ilmiyye, 1999), 1/687.

24 İbrahim Enîs, fi'l-Lehecati'l-'Arabiyye (Kahire: Mektebetu'l-enclu el-Masriyye, 2003), 15.

25 Aytaç, Arap Lehçelerindeki Türkçe Kelimeler, 11.

${ }^{26}$ Murat Yıldız, "Standart ve Yerel Arapçanın Tarihsel ve Filolojik Sınırları”, Dinbilimleri Akademik Araştırma Dergisi 10/3 (2010), 24.

27 Şakir el-'Amiri - Ali Diğmi, “en-Namtu'l-cenûbî fi'l-lehceti'l-'Irakiyye: Tarih ve Tatavvur”, el-Cem'iyyetu'l'ilmiyye el-İraniyye li-l'lugati'l-'Arabiyye ve Âdâbuhâ 8 (2007).41

28 Nevzat Özkan, "Irak Türk Edebi Dilinin Tarih Gelişimi”, International Periodical For the Languages, Literature and History of Turkish or Turkic 4/ 8 (2009), 92.
} 
gelmiştir. Dolayısıyla Arapça dâhil olmak üzere birçok dili etkilemiştir.29 "16. yüzyılda Osmanlı yönetimine geçen Irak, bu tarihten sonra Kanuni' nin Irak seferine kadar İran'la Osmanlı arasında el değiştirmiş ve bu seferden sonra 1. Dünya savaşına kadar Osmanlı yönetiminde kalmıştır." 301639 yılından itibaren Osmanlı yönetimine giren Irak yaklaşık beş asırlık süre zarfında en parlak dönemlerini yaşamıştır. Osmanlı Devleti'nin asırlar süren bu bölgeler üzerindeki hâkimiyeti, Türkçenin Irak Arapçasındaki etkisinin en önemli faktörlerinden biri olmuştur. ${ }^{31}$ Türkçe, Irak Arapçası üzerinde en çok etkisi olan dillerden biri olmuştur. ${ }^{32}$

Türkçe kelimeler ve diğer dillerden Türkçe aracılığıyla Irak Arapçasına geçen kelimeler genellikle Türkçedeki anlamlarını korumuştur, ancak bazı kelimeler zamanla anlam değişikliğine uğramıştır. Kuşkusuz, geçmişte bu değişikliğe yol açan dilsel, tarihsel veya sosyal faktörler vardır. Öte yandan diğer dillerden Türkçe aracılığıyla Arapçaya geçen kelimelerin bazıları Türkçede değişik bir anlam kazandığı için onlar da Türkçeden Arapçaya geçen kelimeler içerisinde ele alınmaktadır.

\section{Anlam Kaymasına Uğramış Kelimeler}

\section{Abla (بكأ):}

Tür. Bir kimsenin kendisinden büyük olan kız kardeşi veya saygı gösterilen kadın³ Arp. Orta yaşlı kadınlar için kullanılır. ${ }^{34}$ Örneğin, ( أبلة عائشة ) "Aişe abla" denir.

\section{Açık (بَ):}

Tür. "Açılmış, kapalı karşıtıdır." 35

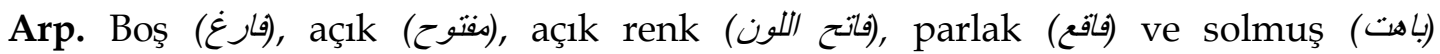
manalarında kullanılır. Bağdat Lehçesi ve Irak'ın bazı bölgelerinde sıkça kullanılır. Genellikle renkler ile ilgilidir. Örneğin, (لابسة ثوب أحمر أجغ) "canlı kırmızı elbise giymiştir" denir. 36

\section{Örnek ()رارن:}

Tür. "Benzeri yapılacak olan, benzetilmek istenen şey, model” anlamındadır. ${ }^{37}$

\footnotetext{
29 Hasan Akreş, "el-Hudûru't-Turkî fî́l-lugati'l-'Arabiyyeti-l-mektûbe", The Islamic University College Journal 2/41 (1997), 18.

30 Yilmaz, Irak Dosyası,17.

31 Akreş, el-Hudûru't-Turkî, 46.

32 Akreş, el-Hudûru't-Turkî, 37.

33 Şükrü Haluk Akalın vd., Türkçe Sözlük (Ankara: TDK, 2011), 5.

34 Akreş, el-Hudûru't-Turkî, 43.

35 Akalın vd., Türkçe Sözlük, 14.

36 Mecid Muhammed Ali el-Kaysi, Mevsu'atu'l-lugati'l-'Âmmiyye el-Bağdâdiyye (Amman: Daru'l-edîb, 2013$), 61$.

37 Akalın vd., Türkçe Sözlük, 1858.
} 
Arp. Bağdat lehçesinde, çeşit manasında kullanılmaktadır. Örneğin (أشكال وأرناك) "Çeşit çeşit" denir. 38

\section{İskemle (إسكملي):}

Tür. "Arkalıksız sandalye" manasındadır. Ayrıca "üstüne sigara tablası, çiçek vazosu vb. konulan küçük masa" 39 için kullanılır.

Arp. Yalnızca sandalye manasında kullanılır. Irak Arapçasında kullanımı yaygındır. ${ }^{40}$

\section{Oğlum (לُ)ر):}

Tür. Erkek evlat manasındadır. Ayrıca "yaşlı kimselerin genç erkeklere söylediği bir seslenme sözüdür". 41

Arp. Şarkıcının söylediği Irak makamının terimlerinden biridir. ${ }^{42}$

\section{Emzik (مز5):}

Tür. "Süt çocuklarını oyalamak için ağızlarına verilen kauçuk meme" anlamındadır. Ayrıca "İbrik, çaydanlık, testi vb. kapların, suyu azar azar akıtmaya yarayan içi delik uzantısı" manasında kullanılır. 43

Arp. Dumanın etkisini azaltmak için sigaranın yerleştirildiği küçük tüp anlamındadır. ${ }^{4}$

\section{Ocak (أوجاغ):}

Tür. “Ateş yakmaya yarayan, pişirme, 1sıtma, 1sınma vb. amaçlarla kullanılan yer ile Şömine" 45 manalarında kullanılır.

Arp. Ocak anlamının yansıra ısıtıcı anlamında da kullanılır. Bağdat'taki kahvehanelerde müşterilere çay ve kahve hala (أوجاغ) ocak ile hazırlanır.46

\footnotetext{
38 Akreş, el-Hudûru't-Turkî, 46.

39 Akalın vd., Türkçe Sözlük, 1208.

40 el-Kiss Tobya el-'Anisi el-Halebî el-Lubnânî, Kitâbu Tefsîri'l-elfâzi'd-dahîle fi'l-lugati'l-'Arabiyye ma'a Zikri Asliha bi Hurûfihi (Misir: Mektebetu'l-'Arab, 1932), 3.

41 Akalın vd., Türkçe Sözlük, 1790.

42 Kaysi, Mevsu'atu'l-lugati'l-'Âmmiyye, 82.

43 Akalın vd., Türkçe Sözlük, 797.

44 Kaysi, Mevsu'atu'l-lugati'l-'Âmmiyye, 75.

45 Akalın vd., Türkçe Sözlük, 1786.

46 Akreş, el-Hudûru't-Turkî, 51.
} 


\section{Ölçü (ولجِي):}

Tür. "Bir niceliği, o nicelik için kabul edilmiş birimlerden birine göre oranlayarak değerlendirme ve bu değerlendirmede kullanılan birim, ölçme birimi" 47 anlamındadır.

Arp. Terzinin ölçü alması (قياس البلّة) manasında kullanılır.48

\section{Ayri (آيري):}

Tür. “Başka, başka türlü, yalnız ve tek başına”49 manalarında kullanılır.

Arp. Bağdat lehçesinde ayrı (غير) ve diğer (خرخ) anlamlarında kullanılır.50 Bunula

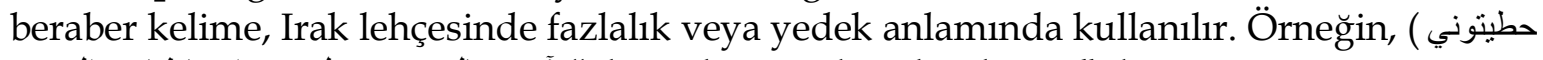
"ekipte beni yedeğe bıraktınız" denir.51

\section{Bac1 (باجي):}

Tür. Kız kardeş veya büyük kız kardeş için kullanılır. ${ }^{52}$

Arp. Gençlerin aile üyelerinden yaşlı olan kadınlara (لنسوة الأكبر سنا) seslenme şeklidir.53

\section{Badem (بادم):}

Tür. “Badem ağacının yaş veya kuru yenilen yemişi." 54

Arp. (نوع من الحلويات وتكوّن من جوز الهند المبروش مع طحين) Unlu, ezilmiş Hindistan cevizinden yapılan bir çeşit tatlıdır. ${ }^{55}$

\section{Para ()بإِرة):}

Tür. “Devletçe bastırılan, üzerinde değeri yazılı kâğıt veya metalden ödeme aracı."56

Arp. Para anlamının yansıra, insanı küçümsemek, kalitesizlik veya değer eksikliği manalarında kullanılır. Örneğin, (هذا بارة ما ببسوه ، أي: لا بيساوي فلس ), "bu tek kuruş etmez" denir.57

\footnotetext{
47 Akalın vd., Türkçe Sözlük, 1844.

48 Kaysi, Mevsu'atu'l-lugati'l-'Âmmiyye, 83.

49 Akalın vd., Türkçe Sözlük, 209.

50 Akreş, el-Hudûru't-Turkî, 54.

51 Akreş, el-Hudûru't-Turkî, 54: Leys Rauf Hasan, el-Mu'cem li'l-kelimâti ve'l-mustalahâti'l-'Irâkinyye (Dubai, 2013), 29.

52 Akalın vd., Türkçe Sözlük, 222.

53 Kaysi, Mevsu'atu'l-lugati'l-'Âmmiyye, 91.

54 Akalın vd., Türkçe Sözlük, 223.

55 Hasan, el-Mu'cem li'l-kelimâti, 30.

56 Akalın vd., Türkçe Sözlük, 1883.

57 Akreş, el-Hudûru't-Turkî, 57.
}

Journal of Analytic Divinity, https://dergipark.org.tr/tr/pub/jad Volume 4/1 


\section{Biçim (جֶِ):}

Tür. "Bir nesnenin dış çizgileri bakımından niteliği, dıştan görünüşü." 58

Arp. Biçim, şekil, çehre ${ }^{59}$ anlamının yansıra, çirkin anlamında kullanılır. Örneğin, (عن (عاب هال بجٍ أي: ماأقبحك

\section{Beraber (برابر):}

Tür. Birlikte, bir arada ${ }^{61}$ anlamındadır.

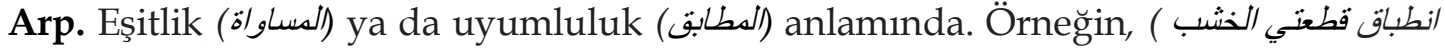
(أو غيره تصام الانطباق , İki parça odun veya benzerinin tamamen eşitliği.62

\section{Balta (بطة):}

Tür. "Ağacı kesme, yarma, yontma vb. işlerde kullanılan ağaç saplı, demir araç" anlamindadır.

Arp. Balta manasının yansıra, sahtekâr ve kötü niyetli kimse için "Baltacı" (بطجي) kelimesi mecazi anlamda kullanılır. ${ }^{64}$

\section{Pencere (بنجمرة):}

Tür. Yapıları havalandırmak amacıyla yapılan, çerçeve, cam gibi eklentilerle daha kullanışlı bir duruma getirilen açıklık. ${ }^{65}$

Arp. Güneşi ve görmeyi kısmen engellemek için pencerenin önüne yerleştirilmiş perde (ستار).66

\section{Tahta Çürük (ختتة جرك):}

Tür. "Çürümüş olan, sağlam ve dayanıklı olmayan." 67

Arp. Özensiz bir işi (عل غير متقن) tanımlamak için ya da güvenli olmayan adımlar konusunda uyarmak için kullanılır. Bağdat'ta kullanımı yaygındır. ${ }^{68}$

\footnotetext{
58 Akalın vd., Türkçe Sözlük, 331.

59 Hasan, el-Mu'cem li'l-kelimâti, 37.

60 Akreş, el-Hudûru't-Turkî, 72: Kaysi, Mevsu'atu'l-lugati'l-'Âmmiyye, 103.

61 Akalın vd., Türkçe Sözlük, 310.

62 Kaysi, Mevsu'atu'l-lugati'l-'Âmmiyye, 106.

63 Ahmed 'Isa Bek, el-Muhkem fî̀ Usul'il-kelimâti'l-Âmiyye (Mısır, 1939), 39.

64 Akreş, el-Hudûru't-Turkî, 63.

65 Akalın vd., Türkçe Sözlük, 1909.

66 Kaysi, Mevsu'atu'l-lugati'l-'Âmmiyye, 127.

67 Akalın vd., Türkçe Sözlük, 572.

68 Kaysi, Mevsu'atu'l-lugati'l-'Âmmiyye, 147.
} 


\section{Terlik (ترليك):}

Tür. "Genellikle ev içinde giyilen, deri, naylon vb. şeylerden yapılan ayak giysisi."69

Arp. Hafif ve şık bayan ayakkabısı (حذاء نسائي) için kullanılır.70

\section{Çember (جصڤبر):}

Tür. "Merkez denilen sabit bir noktadan aynı uzaklık ve düzlemdeki noktalar kümesinin oluşturduğu kapalı eğri ve bu biçime getirilmiş katı cisimlerin çevresi." 71

Arp. Türkçedeki çember anlamıla benzer anlamda kullanımının yansıra, eşyaları sergilemek veya pazarlamak için çarşılarda seyyar satıcıları tarafından kullanılan el arabası için kullanılır. ${ }^{72}$ Kelime ayrıca küçük büfe anlamında kullanılır. ${ }^{73}$

\section{Çark (هُ):}

Tür. "Bir eksenin döndürdüğü tekerlek biçimindeki makine parçası." 74

Arp. Genel olarak otomobil ve taşıtların tekerliğgi (عجلة السيارة والعربات) için kullanılır. (جرخجي) "çarkçı" ise; evlerin arasında düzenli olarak dolaşan bekçidir.75

\section{Çuval (جوال):}

Tür. "Pamuk, kenevir veya sentetik iplikten dokunmuş büyük torba."76

Arp. Çuval anlamında. Kelime ayrıca eşya manasında kullanılır. Örneğin, شال جو الاته "eşyalarını alıp gitti" denir.

\section{Çivi (جِووي):}

Tür. "İki şeyi birbirine tutturmak, bir nesneyi bir yere sabitlemek için çakılan ufak çubuk, mih."77

Arp. Vidayı duvara bağlayan boru şeklinde plastik bir malzeme için kullanılır. Irak'ın bazı bölgelerinde kullanımı yaygındır. ${ }^{78}$

\footnotetext{
69 Akalın vd., Türkçe Sözlük, 2331.

70 Kaysi, Mevsu'atu'l-lugati'l-'Âmmiyye, 149.

71 Akalın vd., Türkçe Sözlük, 518.

72 Hasan, el-Mu'cem li'l-kelimâti, 120.

73 Akreş, el-Hudûru't-Turkî, 97.

74 Akalın vd., Türkçe Sözlük, 497.

75 Hasan, el-Mu'cem li'l-kelimâti, 99.

76 Akalın vd., Türkçe Sözlük, 571.

77 Akalın vd., Türkçe Sözlük, 552.

78 Akreş, el-Hudûru't-Turkî, 99.
} 


\section{Çinko (جينيكو):}

Tür. "Mavimsi beyaz renkte olan sert bir element."79

Arp. Çinko ile kaplı demirden teneke (صفيح من الحديد) için kullanılır. Düz ve çizgili çeşitleri vardır. 80

\section{Han (نان):}

Tür. "Yol üzerinde veya kasabalarda yolcuların konaklamalarına yarayan yapı." 81

Arp. İmalathane (مصنع للبضائع) veya çarş1 (سوق) manasındadır. Kelime; yolcuları karşılamak için umuma açık yerlerde yaygın bulunan haneler' den (لخانات) gelmiştir, fakat daha sonra depo ve alışveriş yerlerine dönüştürülmüştür.82 Bağdat'ta C1ğan han1 (خان جنان), Zurur hanı (خان زرور) ve Kabuli hanı (خان الكابولي) gibi birçok büyük Haneler tanınmıştır.83

\section{Züğürt (ركرتي):}

Tür. "Parasız, yoksul, meteliksiz olan (kimse)." 84

Arp. Bazen yoksul (الكفلس ، الدعدم) anlaminda kullanilırken bazen de bekâr kimse (الكعزب) için kullanılır. ${ }^{85}$

\section{Serbest (سريت):}

Tür. "Hiçbir şarta bağlı olmayan, istediği gibi davranabilen, erkin." 86

Arp. Irak Arapçasında "serbet" (سربت) kelimesi bir şeyi heba etmek, heder etmek anlamlarında kullanilır. "Serbut" (لسربوت) ise; insanlara faydası olmayan yararsız kimse demektir. "İmserbet" ( إسربت ) ifadesi de başıboş bırakılan anlamına gelir.87

\section{Şilte (شنتلة:}

Tür. "Üstünde oturulan, yatılan, içi yünle, pamukla doldurulmuş döşek." 88

Arp. Yatak fermuar1 (محبس الفر/ش) ve yatak k1lıf1 (غلاف الفر/ش) manalarında kullanılır.89

\footnotetext{
79 Akalın vd., Türkçe Sözlük, 549.

80 Kaysi, Mevsu'atu'l-lugati'l-'Âmmiyye, 189.

81 Akalın vd., Türkçe Sözlük, 1040.

82 Hasan, el-Mu'cem li'l-kelimâti, 144.

83 Kaysi, Mersu'atu'l-lugati'l-'Âmmiyye, 194.

84 Akalın vd., Türkçe Sözlük, 2666.

85 Hasan, el-Mu'cem li'l-kelimâti, 200.

86 Akalın vd., Türkçe Sözlük, 2069.

87 Hasan, el-Mu'cem li'l-kelimâti, 215.

88 Akalın vd., Türkçe Sözlük, 2225.

89 Kaysi, Mevsu'atu'l-lugati'l-'Âmmiyye, 271.
} 


\section{Avantac1 (عونطجي):}

Tür. Beleşçi, bedavac1. ${ }^{90}$

Arp. Irak Arapçasında hileli (محتال) ve aldatıcı (مخادع) anlamlarında kullanılır. ${ }^{91}$

\section{Kav (واو):}

Tür. "A ğaçların gövdesinde veya dallarında yetişen bir tür mantardan elde edilen ve çabuk tutuşan, süngerimsi madde." 92

Arp. Türkçeden farklı olarak Irak Arapçasında, kuru, sert manasında kullanılır. Örneğin, sert olmuş manasında; (صار الخبز مثل القاو (ekmek kav gibi olmuş" denir.93

\section{Kursak (قرصاغ):}

Tür. Boğaz. ${ }^{94}$

Arp. Sabır (لصبر) ve katlanmak (لتحمّل) manasında kullanılır. Örneğin, (ماعدي قرصاغ)) "dayanacak gücüm kalmadı" denir. 95

\section{Kalemtıraş (قلم طراش):}

Tür. "Kurşun kalemleri açmak için kullanılan keski, kalem açacağı." 96

Arp. Cam ve ayna üreticilerinin terimlerden biridir (من مصطلحات الزجّاجين وصانعي المرايا) ve yumuşatma (التنعيم) manasında kullanılır.97

\section{Köşe (كوثة):}

Tür. "Birbirini kesen iki çizginin, iki düzlemin oluşturduğu açı, zaviye." 98

Arp. Kanepelerde kullanılan küçük yuvarlak bir yastık (مخدة مدوّرة صغيرة) anlamında kullanilır. ${ }^{99}$

\footnotetext{
90 Akalın vd., Türkçe Sözlük, 190.

91 Kaysi, Mevsu'atu'l-lugati'l-'Âmmiyye, 297.

92 Akalın vd., Türkçe Sözlük, 1355.

93 Kaysi, Mevsu'atu'l-lugati'l-'Âmmiyye, 313.

94 Akalın vd., Türkçe Sözlük, 1532.

95 Kaysi, Mevsu'atu'l-lugati'l-'Âmmiyye, 316.

96 Akalın vd., Türkçe Sözlük, 1278.

97 Kaysi, Meosu'atu'l-lugati'l-'Âmmiyye, 319.

98 Akalın vd., Türkçe Sözlük, 1505.

99 Akreş, el-Hudîru't-Turk̂̂, 174.
} 


\section{Küme (كومة):}

Tür. "Birbirine benzer şeylerin oluşturduğu bütün, takım, öbek, grup."100

Arp. Çokluk, fazlalık anlamında. Örneğin, (أكو كومة ناس بالشارع) "sokakta çok fazla insan var" denir. Irak'ın genelinde kullanımı yaygındır.101

\section{Maşa (ماشة):} araç." 102

Tür. "Ateş veya kızgın bir şey tutmaya, korları karıştırmaya yarayan iki kollu metal

Arp. Irak Arapçasında Kelimenin iki farklı kullanım şekli vardır. Türkçedeki maşa103 anlamının yansıra, saçı bağlamak için kullanılan saç tokası (مشبك الشعر) anlamında da kullanılmaktadır. ${ }^{104}$

\section{Sonuç}

Farklı dilleri konuşan halklar arasındaki siyasi, ticari, sosyal ve kültürel ilişkiler zamanla bu halkların dilleri arasında etkileşimin ortaya çıkmasına yol açmıştır. Araplar ve Türkler, ortak İslam medeniyetinden ötürü derin tarihi ve kültürel bağlara sahiptir. Söz konusu faktörler iki dil arasında karşılıklı etkileşimin yaşanmasına neden olmuştur. Her iki dilin birbirinden etkilenmesi kaçınılmaz olmuştur. Bu bakımdan Türkçe, Arapçadan yoğun olarak etkilenmiş, Arapçanın Türkçeyi etkisi kadar olmasa da Türkçe de Arapçayı etkilemiş ve bu etkisinin günümüze kadar devam ettiğini görmekteyiz.

Türkçe, Irak Arapçası üzerinde en çok etkisi olan dillerden biridir. Osmanlı devletinin dört yüzyıldan fazla süren Irak bölgesi üzerindeki hâkimiyeti, Türkçenin Irak Arapçasında etkili olmasını sağlamış ve Türkçeden birçok kelimenin Irak Arapçasına aktarılmasına yol açmıştır. Irak Arapçasına geçen Türkçe kelimeler genellikle Türkçedeki anlamlarını koruyarak kullanılmaktadır, ancak Yukarıdaki tespit ettiğimiz kelimelerden de anlaşılacağı üzere bazı kelimeler, Irak Arapçasında Türkçedeki anlamlarından tamamen farklı bir anlamda kullanılırken bazıları ise, Türkçedeki anlamı ile birlikte yeni anlamlar kazanarak kullanılır hale gelmiştir. Kuşkusuz, geçmişte bu değişikliğe yol açan dilsel, tarihsel veya sosyal faktörler olmuştur.

\section{Kaynakça}

Akalın, Şükrü Haluk vd.. Türkçe Sözlük. Ankara: TDK, 2011.

\footnotetext{
100 Akalın vd., Türkçe Sözlük, 1559.

101 Akreş, el-Hudûru't-Turkî, 175.

102 Akalın vd., Türkçe Sözlük, 1633.

103 Kaysi, Mevsu'atu'l-lugati'l-'Âmmiyye, 373.

104 Hasan, el-Mu'cem li'l-kelimâti, 402.
} 
Akreş, Hasan. el-Hudûru't-Turkî fíl-lehceti'l-'Irâkiniyye. Bağdat: Daru'ş-şuûni's-sakafiyyeti'l‘âmme, 2018.

Akreş, Hasan. "el-Hudûru't-Turkî fî́l-lugati'l-'Arabiyyeti-l-mektûbe". The Islamic University College Journal 2/41 (1997), 17-29.

Alp, Musa. "Farklı İki Açıdan Arapça: Fusha ve Avamca". Çukurova Üniversitesi İlahiyat Fakültesi Dergisi 11/2 (2011), 87-110.

Alp, Musa. "Kelimelerin Göçü: Türkçe Nisbet Eki “-Ci' nin” Şam Bölgesi (Suriye, Ürdün, Filistin ve Lübnan)" Arap Halk Ağzında Kullanımı Hakkında Bir Araştırma". Çukurova Üniversitesi İlahiyat Fakültesi Dergisi 7/1 (2007),179-226.

'Amiri, Şakir - Diğmi, Ali el-. "en-Namtu'l-cenûbî fi'l-lehceti'l-'Irakiyye: Tarih ve Tatavvur", el-Cem'iyyetu'l-'ilmiyye el-İraniyye li-l'lugati'l-'A rabiyye ve Âdâbuhâ 8 (2007).41-62.

Aslan, Hussein Abbas Ali Muhammed. Kraliyet Devrinde Irak'ın Etnik Yapisi ve Siyasi Oluşumlar. Ankara: Gazi Üniversitesi, Sosyal Bilimler Enstitüsü, Yüksek Lisans Tezi, 2009.

Aytaç, Bedrettin. Arap Lehçelerindeki Türkçe Kelimeler. İstanbul: Türk Dünyası Araştırmaları Vakfı, 1994.

Bek, Ahmed 'Isa. el-Muhkem fì Usûli'l-kelimâti'l-Âmmiyye. Misır: Matbaatu Mustafa el-Babi el-Halebi,1939.

Enîs, İbrahim. fi'l-Lehecati'l-'A rabiyye. Kahire: Mektebetu'l-enclu el-Masriyye, 2003.

Dakûkî, İbrâhim ed-. "Irak (Kültür ve Medeniyet)". Türkiye Diyanet Vakfi Islaîn Ansiklopedisi. 19/103-108. İstanbul: Yay., 1999.

Hadîsî, Nezâr vd. el-. Hadaretu'l-'Irak. Bağdat: Daru'l-Huriyye, 1985.

Halîl, İmâdüddin. "Irak (Tarih)”. Türkiye Diyanet Vakfi Islâm Ansiklopedisi. 19/87-91. İstanbul: TDV Yay., 1999.

Hasan, Leys Rauf. el-Mu'cem li'l-kelimâti ve'l-mustalahâti'l-'Irâkiyye. Dubai, 2013.

Hourani, Albert. Arap Halkları Tarihi. çev. Yavuz Alogan. İstanbul: İletişim, 1997.

Karaağaç, Günay. Türkçe Verintiler Sözlüğü. Ankara: TDK., 2008.

Karaalp, Haydar. "Farklı etnik, dini ve mezhebi bileşenlerin mozaiği: Irak". Anadolu Ajansı Erişim 26 Mart 2020. https://www.aa.com.tr/tr/dunya/farkli-etnik-dini-vemezhebi-bilesenlerin-mozaigi-irak-/1641558

Kaysi, Mecid Muhammed Ali el-. Mevsu'atu'l-lugati'l-'Âmmiyye el-Bă̆dâdiyye. Amman: Daru'l-edîb, 2013.

Lubnânî, el-Kiss Tobya el-'Anisi el-Halebî el-. Kitâbu Tefsîri'l-elfâzi'd-dahîle fi'l-lugati'l'Arabiyye ma'a Zikri Asliha bi Hurûfihi. Misır: Mektebetu'1-'Arab, 2. Basım 1932.

Matar vd., Selim. “Lugatu'l-'Irâkî ve'l-'alemî”. Mevsuat'l-luğat'l-'Irakiyye. Beyrut: Daru'lkelimetu'l-hurre, 2009. 
Özeren, Mehmet. "Türkiye Türkçesi ağ1zlarındaki Rusça sözcükler". Turkish Studies International Periodical For The Languages, Literature and History of Turkish or Turkic 9/3 (2014), 1093-1120.

Özey, Ramazan. Dünya Denkleminde Ortadoğu Coğrafyası "Ülkeler-İnsanlar-Sorunlar". İstanbul: Aktif, 3. Basım, 2004.

Özkan, Nevzat. "Irak Türk Edebi Dilinin Tarih Gelişimi". International Periodical For the Languages, Literature and History of Turkish or Turkic 4/8 (2009), 89-107.

Tuncî, Muhammed el-. el-Mu'cemu'l-mufassal fi'l-edeb. 1 Cilt. Beyrut: Daru'l-kütübi'lilmiyye, 2. Basim,1999.

Tüccar, Zülfikar. "Dahîl". Türkiye Diyanet Vakfı Islậ Ansiklopedisi. 8/412-413. İstanbul: TDV Yay., 1993.

Yahya, Şamil Fahri. Arapçanın Muhtelif Lehçelerinde Türkçe Unsurlar. İstanbul: İstanbul Üniversitesi, Doktora Tezi, 1984.

Yakub,İmîl Bedî' - Asi, Mişel. el-Mu'cemu'l-mufassal fi'l-luğa ve'l-edeb. Beyrut: Dâru'l-ilm li'lmelâyîn,1987.

Yıldız, Murat. "Standart ve Yerel Arapçanın Tarihsel ve Filolojik Sinırları". Dinbilimleri Akademik Araştırma Dergisi 10/3 (2010), 23-41.

Yılmaz, Sait. Irak Dosyası. İstanbul: Kum Saati Yay., 2011. 